\title{
The Potential for Electrofuels Production in Sweden Utilizing Fossil and Biogenic $\mathrm{CO}_{2}$ Point Sources
}

\author{
Julia Hansson ${ }^{1,2 \star}$, Roman Hackl', Maria Taljegard ${ }^{3}$, Selma Brynolf ${ }^{2}$ and Maria Grahn ${ }^{2}$ \\ ${ }^{1}$ Climate and Sustainable Cities, IVL Swedish Environmental Research Institute, Stockholm, Sweden, ${ }^{2}$ Division of Physical \\ Resource Theory, Department of Energy and Environment, Chalmers University of Technology, Göteborg, Sweden, ${ }^{3}$ Division \\ of Energy Technology, Department of Energy and Environment, Chalmers University of Technology, Göteborg, Sweden
}

\section{OPEN ACCESS}

Edited by:

Katy Armstrong,

University of Sheffield, UK

Reviewed by:

Hyungwoong Ahn,

University of Edinburgh, UK

Adam Hughmanick Berger,

Electric Power Research Institute,

USA

${ }^{*}$ Correspondence:

Julia Hansson

julia.hansson@ivl.se

Specialty section:

This article was submitted to Carbon

Capture, Storage, and Utilization,

a section of the journal

Frontiers in Energy Research

Received: 23 December 2016

Accepted: 23 February 2017

Published: 13 March 2017

Citation:

Hansson J, Hackl R, Taljegard M,

Brynolf S and Grahn M (2017)

The Potential for Electrofuels

Production in Sweden Utilizing Fossil and Biogenic $\mathrm{CO}_{2}$ Point Sources.

Front. Energy Res. 5:4.

doi: 10.3389/fenrg.2017.00004
This paper maps, categorizes, and quantifies all major point sources of carbon dioxide $\left(\mathrm{CO}_{2}\right)$ emissions from industrial and combustion processes in Sweden. The paper also estimates the Swedish technical potential for electrofuels (power-to-gas/fuels) based on carbon capture and utilization. With our bottom-up approach using European databases, we find that Sweden emits approximately 50 million metric tons of $\mathrm{CO}_{2}$ per year from different types of point sources, with $65 \%$ (or about 32 million tons) from biogenic sources. The major sources are the pulp and paper industry (46\%), heat and power production (23\%), and waste treatment and incineration (8\%). Most of the $\mathrm{CO}_{2}$ is emitted at low concentrations $(<15 \%)$ from sources in the southern part of Sweden where power demand generally exceeds in-region supply. The potentially recoverable emissions from all the included point sources amount to 45 million tons. If all the recoverable $\mathrm{CO}_{2}$ were used to produce electrofuels, the yield would correspond to 2-3 times the current Swedish demand for transportation fuels. The electricity required would correspond to about 3 times the current Swedish electricity supply. The current relatively few emission sources with high concentrations of $\mathrm{CO}_{2}(>90 \%$, biofuel operations) would yield electrofuels corresponding to approximately $2 \%$ of the current demand for transportation fuels (corresponding to 1.5-2 TWh/year). In a 2030 scenario with large-scale biofuels operations based on lignocellulosic feedstocks, the potential for electrofuels production from high-concentration sources increases to 8-11 TWh/year. Finally, renewable electricity and production costs, rather than $\mathrm{CO}_{2}$ supply, limit the potential for production of electrofuels in Sweden.

Keywords: carbon dioxide, $\mathrm{CO}_{2}$ recovering, carbon capture and utilization, carbon recycling, power-to-gas, alternative transportation fuels

\section{HIGHLIGHTS}

- Sweden emits 50 million metric tons of $\mathrm{CO}_{2}$ per year from different types of point sources, the vast majority of which is emitted at low concentrations.

- Of this, $65 \%$ is from biogenic sources, most of which are located in southern Sweden.

- Currently, the high-concentration sources of $\mathrm{CO}_{2}$ in Sweden can provide a potential 1.5-2 TWh electrofuels/year (2\% of current transportation demand). 
- The Swedish potential for electrofuels is currently limited by the electricity required and production costs rather than the amount of recoverable $\mathrm{CO}_{2}$.

\section{INTRODUCTION}

Anthropogenic greenhouse gas (GHG) emissions need to be reduced in order to limit global climate change and reach ambitious climate targets (Pachauri et al., 2014). Carbon dioxide $\left(\mathrm{CO}_{2}\right)$ emissions can be reduced by using less fossil fuels or by using fossil fuels in combination with carbon capture and storage (CCS) or carbon capture and utilization (CCU) [e.g., Cuéllar-Franca and Azapagic (2015), Wismans et al. (2016)]. In Sweden, the overall national vision is for zero net emissions of GHG to the atmosphere by 2050 (likely to be changed to 2045), along with a fossil fuel-independent vehicle fleet by 2030 (Government offices of Sweden, 2009; Swedish Government Official Reports, 2016). An extensive official investigation commissioned by the Swedish government has concluded that a range of options are needed to reduce $\mathrm{CO}_{2}$ emissions from the transport sector, including biomass-based liquid and gaseous fuels (biofuels) along with hydrogen and electricity produced from renewable energy sources (Swedish Government Official Reports, 2013).

However, neither government nor academia have explored electrofuels (i.e., power-to-gas/fuels or synthetic hydrocarbons produced from $\mathrm{CO}_{2}$ and water using electricity), extensively. Interest in electrofuels is on the rise, both in the literature (Graves et al., 2011; Mohseni, 2012; Nikoleris and Nilsson, 2013; Taljegård et al., 2015) ${ }^{1}$ and in terms of demonstration plants in the EU, in some cases, including $\mathrm{CO}_{2}$ capture (Gahleitner, 2013). Studies mainly investigate electrofuels as a (i) technology for storing intermittent electricity [e.g., Streibel et al. (2013), de Boer et al. (2014), Vandewalle et al. (2014), König et al. (2015), Qadrdan et al. (2015), Varone and Ferrari (2015), Zakeri and Syri (2015), Zhang et al. (2015), and Kötter et al. (2016)], (ii) fuel for transport [e.g., Connolly et al. (2014), Ridjan et al. (2014), Larsson et al. (2015)], or (iii) means of producing chemicals [e.g., Ganesh (2013), Perathoner and Centi (2014), and Chen et al. (2016)]. Different types of energy carriers [e.g., methane, methanol, DME (dimethyl ether), gasoline, and diesel] can be produced, which makes electrofuels a potentially interesting option for all transport modes, especially shipping, aviation, and long distance road transport, where the potential for other renewable fuel options, such as electricity and hydrogen, may be limited. Electrofuels may allow increased use of biofuels, if the $\mathrm{CO}_{2}$ associated with their production is used for production of electrofuels instead of being emitted to the atmosphere (Mignard and Pritchard, 2008; Mohseni, 2012; Hannula, 2015, 2016).

$\mathrm{CO}_{2}$ emissions can be captured from various point sources, including industrial processes that produce $\mathrm{CO}_{2}$, such as biofuel production (including anaerobic digestion and fermentation), natural gas processing, steel plants, and oil refineries, fossil and

${ }^{1}$ Brynolf, S., Taljegård, M., Grahn, M., and Hansson, J. (2017). Electrofuels for the transport sector: a review of production costs. Renew. Sust. Energ. Rev. (Submitted). biomass combustion in heat and power plants, or directly from the air.

Many studies have estimated $\mathrm{CO}_{2}$ emissions from point sources in China [e.g., Chen and Chen (2010), Liu et al. (2010), Zhang and Chen (2014)]. Zhang and Chen (2014) used a bottomup approach to estimate $\mathrm{CO}_{2}$ emissions from fuel combustion and the main industrial processes at $7.7 \mathrm{Gt} \mathrm{CO}_{2}$ per year in 2008, with coal as the main source. The potential global supply of $\mathrm{CO}_{2}$ from point sources is estimated in Naims (2016). The total estimated global capturable $\mathrm{CO}_{2}$ supply from point sources amount to approximately 12.7 Gton of $\mathrm{CO}_{2}$ (Naims, 2016). High purity point sources (e.g., fermentation of biomass and ammonia production) and other low cost sources (e.g., bioenergy, natural gas, and hydrogen production) represent in total approximately 0.3 Gton of $\mathrm{CO}_{2}$. Naims (2016) further indicates that there is enough $\mathrm{CO}_{2}$ to meet the estimated global $\mathrm{CO}_{2}$ demand in the near and long term.

In Austria, the iron and steel, cement industry, and power and heat industries are the largest point sources of $\mathrm{CO}_{2}$ emissions (Reiter and Lindorfer, 2015). Biofuel production, a relatively modest point source at about 113 kton in 2013, is considered the most suitable Austrian source for power-to-gas application by Reiter and Lindorfer (2015). A German feasibility study by Trost et al. (2012) identifies a large potential for biogenic $\mathrm{CO}_{2}$ sources, including biogas upgrading, bioethanol plants, and sewage treatment plants. Trost et al. (2012) also found a substantial electrofuels potential of over $130 \mathrm{TWh}$ fuel per year in the form of methane produced using $\mathrm{CO}_{2}$ from industrial processes and biogenic sources. Reiter and Lindorfer (2015) and Trost et al. (2012), both conclude that availability of $\mathrm{CO}_{2}$ will not be a limiting factor for using power-to-gas as a balancing strategy for intermittent renewable power sources (wind power and photovoltaics) in Austria or Germany.

In Sweden, carbon capture is currently implemented at, for instance, Agroetanol in Norrköping. Agroetanol produces grainbased ethanol; the resulting $\mathrm{CO}_{2}$ is purified and sold to the AGA Gas AB. Detailed quantification of current and/or future Swedish $\mathrm{CO}_{2}$ emissions from point sources is, however, lacking in the scientific literature, and there are no assessments of the technical potential for Swedish production of electrofuels. Electrofuels may represent an interesting option in Sweden, that is a forest-rich country, due to the ambitious GHG emission reduction targets in general and specifically in the transport sector. Assessing the Swedish potential for CCS and CCU requires detailed knowledge of the stationary $\mathrm{CO}_{2}$ emissions. The overall impact on $\mathrm{CO}_{2}$ emissions of the production and use of electrofuels mainly depends on the electricity-related $\mathrm{CO}_{2}$ emissions. The Swedish electricity production consists mainly of hydro power and nuclear power implying relatively low GHG emissions.

The overall aim of this paper is to map and quantify stationary Swedish $\mathrm{CO}_{2}$ emissions by concentration, origin, and geographical distribution, as well as investigate the potential for CCU. Specifically, we aim to (i) map and quantify the major point sources of $\mathrm{CO}_{2}$ emissions from industrial and combustion processes in Sweden with a bottom-up approach and estimate the technical potential for $\mathrm{CO}_{2}$ capture or recovery and (ii) estimate the technical potential for production of electrofuels 
in Sweden, as an example of CCU. We analyze the potential for biofuels-related $\mathrm{CO}_{2}$ in the future (a 2030 scenario), since the use of biomass and biofuels is expected to increase and use of fossil fuels decrease. Additionally, we estimate the potential demand for $\mathrm{CO}_{2}$ and electricity corresponding to the use of electrofuels for road transport, heavy trucks, and shipping, at scale, in order to give a first indication of the potential role for electrofuels in transportation in Sweden.

\section{MATERIALS AND METHODS}

This section describes the methodology for estimating both $\mathrm{CO}_{2}$ emissions from major point sources and the potential for capturing and using the emissions.

\section{Assumptions about the $\mathrm{CO}_{2}$ Sources Included}

$\mathrm{CO}_{2}$ emission sources can be divided into diffuse sources (e.g., transport and agriculture) and point sources (e.g., factories and power production). This study uses a bottom-up approach to estimate $\mathrm{CO}_{2}$ emissions from the following point sources in Sweden:

- Industrial process plants (including iron and steel, non-ferrous metal, oil and gas refineries, lime and cement, pulp and paper, chemical, metal, and other similar plants)

- Heat and power production (including biomass, waste, and fossil fuel-fired plants)

- Biofuels production facilities (including ethanol, biogas, and more advanced biofuels).

Emissions data for year 2013 from the European Environment Agency's "European Pollutant Release and Transfer Register" (European Environment Agency, 2015) was used to estimate (i) the available amount of $\mathrm{CO}_{2}$ and (ii) the share of fossil and biogenic $\mathrm{CO}_{2}$, for Swedish point sources, including all sources emitting 0.1 million metric tons of $\mathrm{CO}_{2}$ per year or more. Other $\mathrm{CO}_{2}$ sources are assumed to be negligible (except in the case of biofuels production). The concentration of $\mathrm{CO}_{2}$ for each type of sources was estimated using (Chapel et al., 1999; Bosoaga et al., 2009) (see Table 1). For the purposes of analysis, the concentrations were divided in three ranges: low $(<15$ vol\%), medium (15-90 vol\%), and high (>90 vol\%).

For biofuels plants, the $\mathrm{CO}_{2}$ estimates are based on data gathered by Swedish Energy Agency and Energigas Sverige (2015) and Grahn and Hansson (2015) in 2012-2013. Also, the sources emitting less than 0.1 million metric tons of $\mathrm{CO}_{2}$ per year are included in the case of biofuels since these are relatively pure and, therefore, well suited for electrofuels production. In most biofuels production processes, there is a surplus of $\mathrm{CO}_{2}$ and the $\mathrm{CO}_{2}$ is of high purity (Xu et al., 2010). When biogas is upgraded to transport fuel quality, a cleaning step to remove $\mathrm{CO}_{2}$ is included, resulting in a relatively pure stream of $\mathrm{CO}_{2}$. The $\mathrm{CO}_{2}$ emissions from domestic biofuel production in a 2030 scenario are estimated based on biofuels production scenarios from Grahn and Hansson (2015) and on scenarios for anaerobic digestion and gasification-based biogas production from Dahlgren et al. (2013). Grahn and Hansson (2015) assessed the potential contribution of domestically produced biofuels for transport in Sweden in 2030 based on a mapping of the prospects for current and potential Swedish biofuel producers. Some of the planned biofuels production plants included in the scenario for 2030 have been canceled or put on hold and are, therefore, excluded in this study.

The 2030 scenario was constructed exclusively for biofuel plants because these represent a relatively pure stream of $\mathrm{CO}_{2}$ of particular interest in electrofuels production, and because the use of biofuels is expected to increase in the future. For many biofuels, no extra major purification step is needed in the capture process, which leads to a relatively low capture cost. This can also be assumed for the case of biogas since $\mathrm{CO}_{2}$ is already removed when biogas is upgraded to transport fuel quality. This can be compared to the $\mathrm{CO}_{2}$ capture cost linked to processes requiring an extra purification step like steel and iron, ammonia, refinery, cement, and fossil or biomass combustion plants estimated at $20 €_{2015}-170 €_{2015} /$ ton $\mathrm{CO}_{2}$ in the short term (10-15 years) and $10 €_{2015}-100 €_{2015} /$ ton $\mathrm{CO}_{2}$ in the more long term (Damen et al., 2007; Finkenrath, 2011; Kuramochi et al., 2012, 2013; IEA, 2013). Even though it has been

TABLE 1 | The type of $\mathrm{CO}_{2}$ stream, $\mathrm{CO}_{2}$-concentration range, range of $\mathrm{CO}_{2}$ emissions per unit, and share of recoverable $\mathrm{CO}$, for different point sources in Sweden based on European Environment Agency (2015).

\begin{tabular}{|c|c|c|c|c|}
\hline Production facility and location & Type of $\mathrm{CO}_{2}$ stream & Typical concentration & $\begin{array}{c}\text { Process } \mathrm{CO}_{2} \text { emissions (kton/year) for } \\
\text { smallest and largest plant }\end{array}$ & Recoverable share (\%) \\
\hline Oil and gas refineries & Flue gases, by-product & $3-13$ vol\%a & $122-1,573$ & 90 \\
\hline Power and heat production & Flue gases & $3-13$ vol\% & $104-1,990$ & 90 \\
\hline Iron and steel production & Flue gases & Approx. 15 vol\% & $102-1,540$ & 90 \\
\hline Non-ferrous metal production & Flue gases & Approx. 15 vol\% & $101-256$ & 90 \\
\hline Cement and lime production & Flue gases, by-product & Approx. 14-33 vol\% & $110-1,940$ & 90 \\
\hline Production of chemicals & Flue gases, by-product & $3-13$ vol\%a & $13-620$ & 90 \\
\hline Pulp and paper production & Flue gases & Approx. 15 vol\% & $165-1,740$ & 90 \\
\hline Waste treatment or incineration & Flue gas & Approx. 10 vol\% & 105-837 & 90 \\
\hline Fermentation-based biofuels & By-product & Pure stream & $0.11-154$ & 100 \\
\hline Anaerobic digestion-based biofuels & By-product & >90 vol-\% & $0.14-21$ & 54 \\
\hline Gasification-based biofuels & By-product & >90 vol-\% & $1.84-37$ & 100 \\
\hline Other & Flue gas & $3-13$ vol\% & 134 & 90 \\
\hline
\end{tabular}

For $\mathrm{CO}_{2}$ concentration and recoverability references, see Section "Availability of $\mathrm{CO}_{2}$ for Carbon Capture and Utilization."

a Minor amounts of $\mathrm{CO}_{2}$ are available at higher concentrations (up to 100 vol\%). 
indicated that the cost for carbon capture represents a relatively modest share (a few percent) of the total electrofuel-production cost unless air capture is assumed (Graves et al., 2011; Tremel et al., 2015; Varone and Ferrari, 2015; see text footnote 1), using $\mathrm{CO}_{2}$ from biofuel production represent an attractive source for electrofuel production since more pure streams will likely be used first for economic reasons and the domestic biofuel actors, representing a considerable biofuel production capacity, in order to comply with sustainability requirements need to improve their production processes in terms of $\mathrm{CO}_{2}$ emissions.

Table 1 presents the type of $\mathrm{CO}_{2}$ stream, typical concentration of $\mathrm{CO}_{2}$, the range of $\mathrm{CO}_{2}$ emissions per unit, and the amount of recoverable $\mathrm{CO}_{2}$, for different point sources. Table 2 includes a list of all the biofuel production facilities in operation in 2015, their production capacity and associated $\mathrm{CO}_{2}$ emissions, and the corresponding information for the biofuels plants planned by 2030. Table 3 summarizes the main assumptions used in estimating the amount of $\mathrm{CO}_{2}$ that is available for recovery from current and future biofuels plants.

\section{Availability of $\mathrm{CO}_{2}$ for $\mathrm{CCU}$}

In order for $\mathrm{CO}_{2}$ to be used to produce electrofuels, the gas needs to be separated from other substances in emissions from industrial and combustion processes, such as sulfur dioxide. The concentration of $\mathrm{CO}_{2}$ in power plant flue gases is relatively low (<15 vol\%) (Chapel et al., 1999); for process-related emissions, e.g., in the lime and cement industry, $\mathrm{CO}_{2}$ concentrations are somewhat higher (14-33 vol\%) (Bosoaga et al., 2009) (see Table 1). In this study, we assume that $90 \%$ of the $\mathrm{CO}_{2}$ from medium- (15-90 vol\%) and low- (<15 vol\%) concentration $\mathrm{CO}_{2}$ sources is recoverable (Chapel et al., 1999). Current $\mathrm{CO}_{2}$ capture technologies do not usually capture all the $\mathrm{CO}_{2}$ as this is too expensive and requires too much energy.
In biofuels production processes (fermentation, anaerobic digestion, gasification), relatively pure streams (>90 vol\%) of $\mathrm{CO}_{2}$ are available in latter cases due to the demand for high fuel purity in the transport sector. We assume that $100 \%$ of the $\mathrm{CO}_{2}$ from biofuel plants is recoverable and could be converted into fuel. Approximately 54\% of the biogas produced in Sweden is upgraded for the transportation sector (Swedish Energy Agency and Energigas Sverige, 2016), which means that $\mathrm{CO}_{2}$ capturing technology already exist on several Swedish anaerobic digestion facilities. Another opportunity for anaerobic digestion-based biogas plants is to feed raw biogas to a methanation reactor, thereby combining biogas upgrading and electrofuels production (Johannesson, 2016). Biogas plants that currently do not upgrade their gas are generally small implying high costs for upgrading and currently supplying other markets than the transport sector, making them less suitable as a source of $\mathrm{CO}_{2}$ for electrofuels production. Therefore, only $\mathrm{CO}_{2}$ from biogas-upgrading plants is considered in this study. For simplicity, we assume that the share of upgraded biogas of total biogas production by 2030 remains at $54 \%$.

\section{Geographic Distribution of $\mathrm{CO}_{2}$ Emissions}

The $\mathrm{CO}_{2}$ emission sources have been mapped and categorized by concentration and geographical area. The geographical areas are those used for the Swedish electricity market, i.e., four price areas (SE1, SE2, SE3, and SE4) (Swedish Energy Markets Inspectorate, 2014) (see Figure 1). The electricity price areas were implemented in Sweden in order to control the transmission of electricity between regions and to promote the construction of power generation and transmission capacity in and to areas with electricity deficits. On average, the northern parts of the country (SE1 and SE2) are characterized by an excess of electricity production due to the available hydropower resources and relatively

TABLE 2 | Biofuels production facilities and associated $\mathrm{CO}_{2}$ emissions.

\begin{tabular}{|c|c|c|c|c|}
\hline Production facility and location & Biofuel & $\begin{array}{c}\text { Biofuel } \\
\text { production } \\
\text { (GWh/year) }\end{array}$ & $\begin{array}{c}\text { Process } \mathrm{CO}_{2} \\
\text { emissions } \\
\text { (ton/year) }\end{array}$ & Reference $^{a}$ \\
\hline
\end{tabular}

Facilities operational in 2015

Agroetanol, Line 1, Norrköping

Agroetanol, Line 2, Norrköping

ST1, Göteborg

SEKAB, Örnsköldsvik

SP, pilot plant, Örnsköldsvik

LTU Green Fuels, pilot plant, Piteåc

GoBiGas, Göteborg Energi, Göteborg

Swedish anaerobic digestion-based biogas Biogas production (277 plants)

Additional production capacity until $\mathbf{2 0 3 0}$

Fermentation

Anaerobic digestion

Gasification

$\begin{array}{lcc}\text { Ethanol } & 391 & 53,466^{\mathrm{b}} \\ \text { Ethanol } & 1,126 & 154,014^{\mathrm{b}} \\ \text { Ethanol } & 34 & 4,617 \\ \text { Ethanol } & 64 & 7,807 \\ \text { Ethanol } & 0.9 & 109 \\ \text { DME } & 6 & 1,836 \\ \text { Gasification-based } & 180 & 36,900 \\ \text { biogas } & & \\ \text { Biogas } & 1,686 & 245,680\end{array}$

Ethanol $\quad 3,300$

Biogas

Biogas, methanol,

DME
Axelsson et al. (2014) and Grahn and Hansson (2015)

Axelsson et al. (2014) and Grahn and Hansson (2015)

Axelsson et al. (2014) and ST1 (2016)

Arvidsson and Lundin (2011) and Grahn and Hansson (2015)

Arvidsson and Lundin (2011) and Grahn and Hansson (2015)

Pettersson and Harvey (2012) and Grahn and Hansson (2015)

Heyne (2013) and Grahn and Hansson (2015)

SGC (2012) and Swedish Energy Agency and Energigas Sverige (2016)

402,033 Hansson and Grahn (2013)

672,342 SGC (2012), Dahlgren et al. (2013), and Hansson and Grahn

(2013)

1,023,260 Dahlgren et al. (2013) and Hansson and Grahn (2013)

${ }^{a}$ References for the amount of biofuels produced and the estimated $\mathrm{CO}_{2}$ emissions per unit of fuel are provided here.

${ }^{b} \mathrm{CO}_{2}$ produced at Agroetanol in Norrköping is currently purified and sold to the AGA Gas AB.

cThe closure of this pilot plant was announced in April 2016. 
TABLE 3 | Main assumptions for assessing $\mathrm{CO}_{2}$ availability from current and future biofuels plants in Sweden.

\begin{tabular}{|c|c|}
\hline Production technology & $\begin{array}{l}\text { Assumed amount of available } \mathrm{CO}_{2} \text { per } \mathrm{GWh} \\
\text { biofuel }\end{array}$ \\
\hline Fermentation & $\begin{array}{l}\text { Cereal based: } 136.8 \text { ton } \mathrm{CO}_{2} / \mathrm{GWh} \text { (Axelsson et al., } \\
\text { 2014) } \\
\text { Lignocellulose based: } 121.7 \text { ton } \mathrm{CO}_{2} / \mathrm{GWh} \text { (Arvidsson } \\
\text { and Lundin, 2011) }\end{array}$ \\
\hline Anaerobic digestion & Upgraded biogas: 145.7 ton $\mathrm{CO}_{2} / \mathrm{GWh}(\mathrm{SGC}, 2012)$ \\
\hline Gasification & $\begin{array}{l}\text { Black liquor gasification: } 305 \text { ton } \mathrm{CO}_{2} / \mathrm{GWh} \\
\text { (Pettersson and Harvey, 2012) } \\
\text { Indirect gasification: } 206 \text { ton } \mathrm{CO}_{2} / \mathrm{GWh} \text { (Heyne, 2013) }\end{array}$ \\
\hline
\end{tabular}

low overall power consumption. In the southern parts (SE3 and SE4), electricity consumption often exceeds production, which leads to relatively higher electricity prices in these areas (Nord Pool, 2016).

\section{Electrofuel-Production Efficiency and Cost}

The focus in this study is on electrofuels in the form of methane, methanol, and DME since these are the most discussed electrofuels in the literature (see text footnote 1), are of interest for the relevant transport sector (shipping and trucks), and include fuels in liquid and gaseous form. The amounts of $\mathrm{CO}_{2}$ and electricity necessary for the types of electrofuels included in this study are given in Table 4 and are based on lower heating value (LHV).

Table 4 also presents cost ranges for 2015 and 2030 estimated in the base case reference scenario in Brynolf et al. (see text footnote 1). The electricity-to-fuel efficiency of the electrofuelproduction process strongly depends on the type of electrolyzer and the future development of production technologies. Alkaline electrolysers have efficiencies in the range of 43-69\% today, while the most efficient electrolysers are expected to reach efficiencies above $80 \%$ based on LHV (Smolinka et al., 2011; Benjaminsson et al., 2013; Grond et al., 2013; Mathiesen et al., 2013; Bertuccioli et al., 2014; Hannula, 2015; Schiebahn et al., 2015). Combining this with the efficiency for fuel synthesis yields electricity-to-fuel efficiencies in the 30-75\% range for methane, methanol, and DME, this corresponds to an electricity demand of 1.33-3.33 MWh electricity/MWh electrofuel.

Brynolf et al. (see text footnote 1) suggest costs for different electrofuels (methane, methanol, DME, gasoline, and diesel) in the span of $120 €_{2015}-1,050 €_{2015} / \mathrm{MWh}_{\text {fuel }}$ and $100 €_{2015}-430 €_{2015} /$ $\mathrm{MWh}_{\text {fuel }}$ in 2015 and 2030, respectively. However, in the base case of the reference scenario representing average data, the same costs are $200 €_{2015}-280 €_{2015} / \mathrm{MWh}_{\text {fuel }}$ and $160 €_{2015}-210 €_{2015} /$ $\mathrm{MWh}_{\text {fuel }}$ in 2015 and 2030, respectively. The most important factors affecting the production cost of electrofuels are the capital cost of the electrolyzer, the electricity price, the capacity factor of the unit, and the lifetime of the electrolyzer. The base case reference scenario assumes alkaline electrolyzer with a capital cost of $600 €_{2015} / \mathrm{kW}_{\mathrm{el}}$, capacity factor of $80 \%$, lifetime of the electrolyzer at 25 years, carbon capture cost at $30 €_{2015} /$ ton, and electricity price of $50 €_{2015} / \mathrm{MWh}$. A capacity factor at $80 \%$ implies that the plant is run the major part of the year. However, if electrofuels are used to balance intermittent renewable power production (i.e., there is production only when there

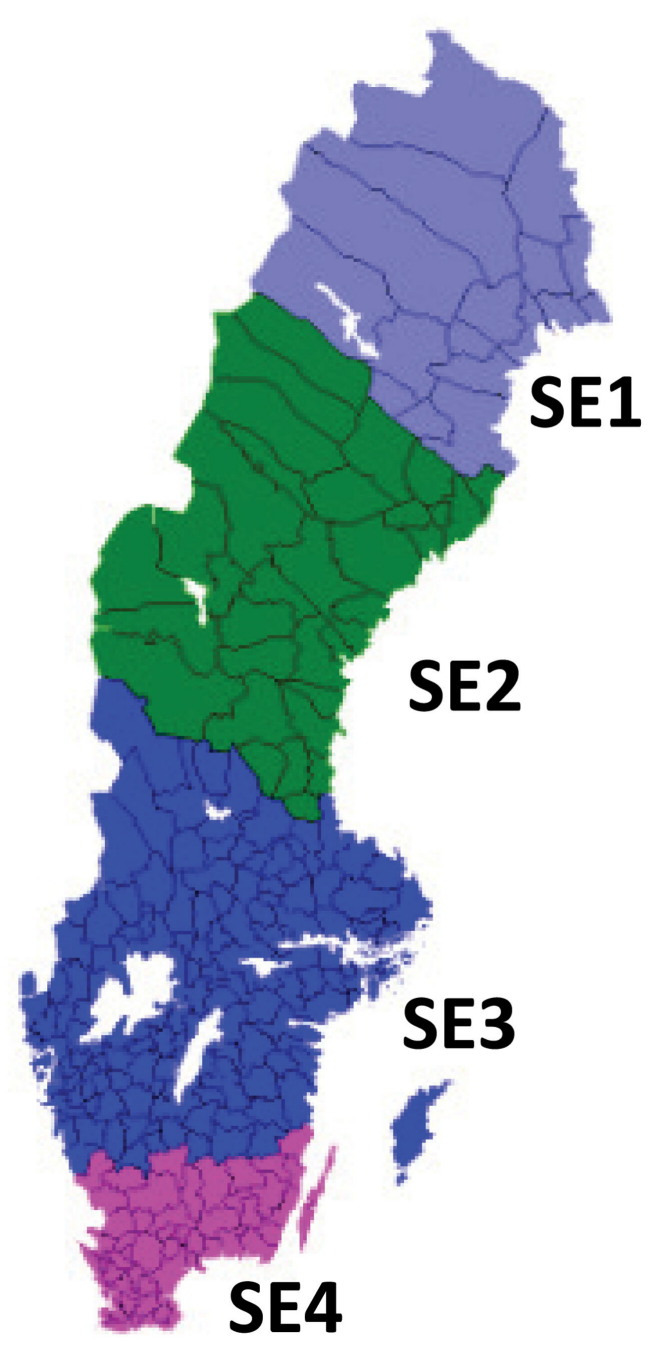

FIGURE 1 | The electricity price areas (SE1, SE2, SE3, and SE4) in Sweden, which are used to illustrate the geographic distribution of the $\mathbf{C O}_{2}$ emissions. Figure based on SCB (2015).

is a surplus of power from these sources), the capacity factor will be reduced. This will not influence the estimated technical potential for production of electrofuels in Sweden in this study, but it will lead to increased electrofuel-production costs [which is further assessed in Brynolf et al. (see text footnote 1)]. In the case of a carbon capture cost at $10 €_{2015} /$ ton representing more pure streams like biofuels operation, the production cost of electrofuels is reduced by approximately $3 \%$. In their review of the literature, Brynolf et al. (see text footnote 1) also found that the cost of capturing $\mathrm{CO}_{2}$ generally is a minor factor in the total production cost of electrofuels representing less than $10 \%$ (when not considering $\mathrm{CO}_{2}$ capturing from air). $\mathrm{CO}_{2}$ can be captured from various industrial sources with costs ranging from about $10 €_{2015}$ to $170 €_{2015} /$ ton $\mathrm{CO}_{2}$, depending on the $\mathrm{CO}_{2}$ concentration (Damen et al., 2006, 2007; Finkenrath, 2011; Goeppert et al., 2012; Kuramochi et al., 2012, 2013; IEA, 2013; see text footnote 1 ). This indicates that from an economic point 
TABLE 4 | Estimated values for $\mathrm{CO}_{2}$ and electricity demand per unit of electrofuel and production cost for 2015 and 2030 (based on literature review and base case reference scenario by Brynolf et al. (see text footnote 1) representing average data and based on lower heating value, for assumptions see the text).

\begin{tabular}{|c|c|c|c|c|c|}
\hline Electrofuel & $\begin{array}{l}\text { Fuel synthesis } \\
\text { efficiency (\%) }\end{array}$ & $\begin{array}{c}\mathrm{CO}_{2} \text { per unit of fuel } \\
\left(\mathrm{t} / \mathrm{MWh}_{\text {fuel }}\right)\end{array}$ & $\begin{array}{l}\text { Electricity per unit of fuel } \\
\left(\mathrm{MWh}_{\mathrm{el}} / \mathrm{MWh}_{\text {fuel }}\right)\end{array}$ & $\begin{array}{l}\text { Production cost } 2015\left(\epsilon_{2015} /\right. \\
\left.M W^{\text {fuel }}\right)\end{array}$ & $\begin{array}{l}\text { Production cost } 2030 \\
\left(\epsilon_{2015} / \mathrm{MWh}_{\text {fuel }}\right)\end{array}$ \\
\hline Methane & $77^{a}$ & 0.21 & 2.00 & 200 & 160 \\
\hline Methanol & $79^{b}$ & 0.28 & 1.93 & 210 & 160 \\
\hline DME & $80^{b}$ & 0.27 & 1.95 & 210 & 160 \\
\hline
\end{tabular}

aMohseni (2012), Grond et al. (2013), Schiebahn et al. (2015), and Tremel et al. (2015).

bHannula and Kurkela (2013) and Tremel et al. (2015).

of view, all $\mathrm{CO}_{2}$ sources (except from pure air) might be of interest for electrofuel production in the future.

\section{RESULTS}

\section{$\mathrm{CO}_{2}$ Emissions in Sweden}

In Sweden, major stationary point sources currently emit approximately $50 \mathrm{Mton} \mathrm{CO}_{2}$ per year. Of this, about $45 \mathrm{Mton} \mathrm{CO}_{2}$ is recoverable (see Figure 2). Our analysis includes 148 facilities, with $14 \mathrm{U}$ emitting more than 1 Mton $\mathrm{CO}_{2} /$ year, $88 \mathrm{U}$ emitting between $1 \mathrm{Mton}$ and $100 \mathrm{kton} \mathrm{CO}_{2} /$ year, and $47 \mathrm{U}$ emitting less than $100 \mathrm{kton} /$ year.

Figure 2 shows the distribution of $\mathrm{CO}_{2}$ emissions among different types of point sources. Pulp and paper plants and heat and power plants are the two major types of point sources, corresponding to 23 Mton $\mathrm{CO}_{2}$ (45\% of the total) and $11.5 \mathrm{Mton} \mathrm{CO}_{2}$ (23\% of the total) per year, respectively. In total, biogenic sources account for $65 \%$ or $32 \mathrm{Mton}$ of $\mathrm{CO}_{2}$ emissions per year. The high share of biogenic $\mathrm{CO}_{2}$ is mainly due to the extensive use of biomass in producing pulp, paper, heat, and power and from waste treatment and incineration. Emissions from biofuel production represent a small share of the current total amount of available $\mathrm{CO}_{2}$, with approximately 0.5 Mton of recoverable $\mathrm{CO}_{2}$ per year. According to Andreas Gundberg, Innovation manager at Lantmännen Agroetanol, CCU has already been implemented at the main Swedish ethanol producer representing approximately $90 \%$ of the total Swedish ethanol production capacity. The emissions from this ethanol production (about $100 \mathrm{kton} / \mathrm{year}$ ) are included in the analysis.

Figure 3 shows the amount of $\mathrm{CO}_{2}$ available and the corresponding potential production of electrofuels in the form of methanol at different $\mathrm{CO}_{2}$ concentrations in Sweden in 2013 and in 2030. The majority of the $\mathrm{CO}_{2}$ is available at low and medium concentrations, equally spread between the categories low and medium but mainly below $20 \mathrm{vol} \%$. A small share of the $\mathrm{CO}_{2}$, mainly from the biofuels industry, is available at higher, significantly more accessible, concentrations.

About $90 \%$ of the high-concentration emissions come from sources in geographic region SE3, along with about $60 \%$ of the rest of the $\mathrm{CO}_{2}$ emission sources (see Figure 4). Anaerobic digestion and ethanol production from agricultural crops currently dominate biofuels production, and these are mostly located in densely populated areas (producing biogas from digestion of sewage sludge and food waste) or in proximity to agricultural

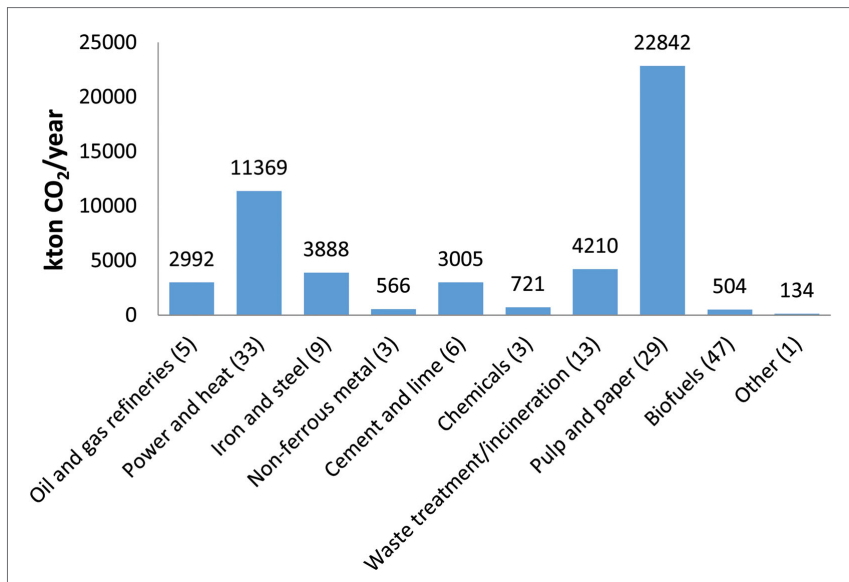

FIGURE 2 | Current recoverable $\mathrm{CO}_{2}$ from major point sources in Sweden, based on European Environment Agency (2015), Grahn and Hansson (2015), and Dahlgren et al. (2013). In total, 149 point sources are included; the number of plants in each category is given in parenthesis.

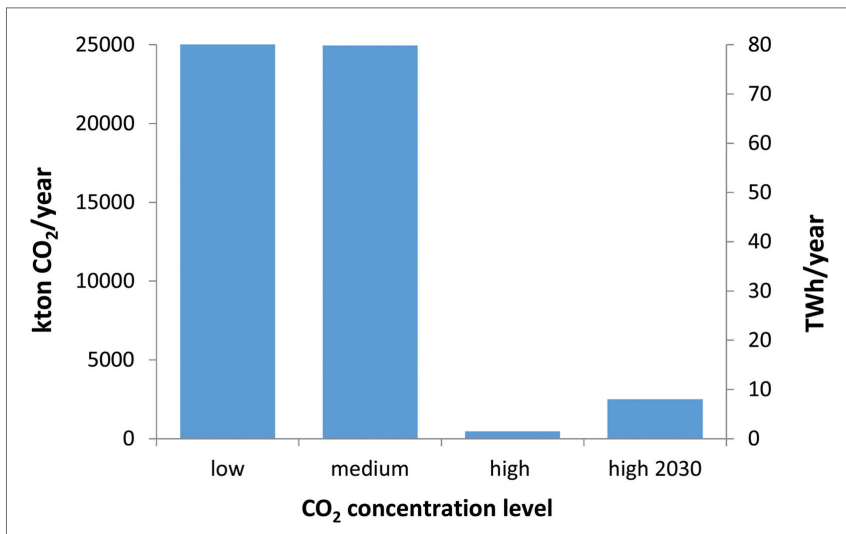

FIGURE 3 | Recoverable $\mathrm{CO}_{2}$ and potential for production of electrofuels in the form of methanol at three different concentration levels (low: $<15$ vol\%, medium: $15-90$ vol\% and, high: $>90$ vol\%) in 2013 and at high concentration in 2030.

operations (farm-based ethanol and biogas production), which are mainly found in southern Sweden. However, electricity prices in the southern parts are currently less favorable than further north where hydropower resources and lower demand create 

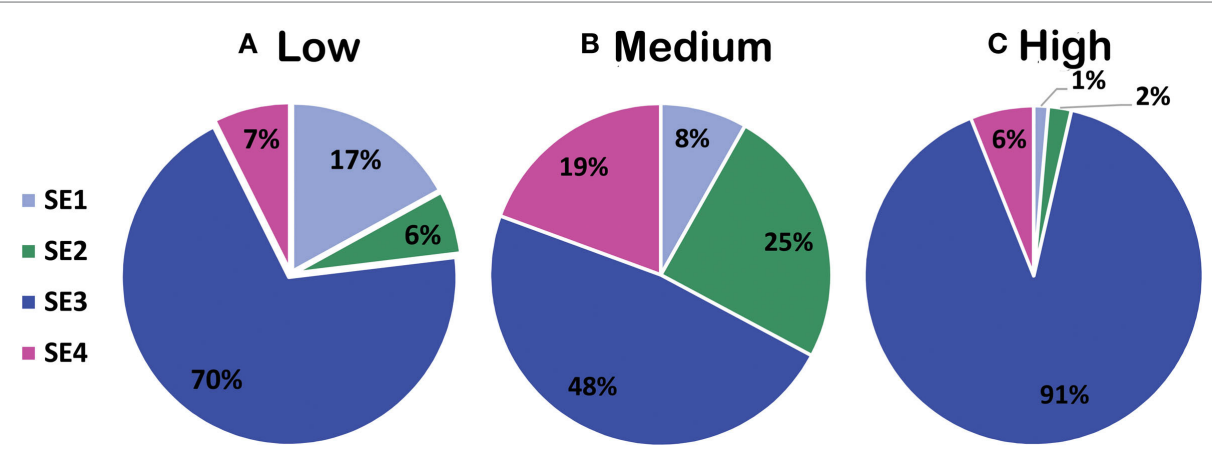

FIGURE $4 \mid \mathrm{CO}_{2}$ point sources by region and concentration level. (A) Low, (B) medium, and (C) high.

an excess of electricity while the transmission capacity to the southern industrial and population centers is limited.

The projected large-scale introduction of biofuels based on lignocellulosic feedstocks should entail higher shares of highconcentration $\mathrm{CO}_{2}$ emissions in the northern regions, SE1 and SE2, if plants are located near feedstock resources.

The biofuels sector is expected to grow significantly in Sweden during the coming years in order to achieve national climate and transport targets. Figure 5 illustrates the current and estimated amount of $\mathrm{CO}_{2}$ available for electrofuels production from different biofuel production technologies and a minor share of others sources available by 2030 in Sweden based on Dahlgren et al. (2013) and Hansson and Grahn (2013). Only $\mathrm{CO}_{2}$ from the production of upgraded biogas is included. In 2030, the $\mathrm{CO}_{2}$ originates mainly from gasification, anaerobic digestion, and fermentation-based biofuels production (utilizing both cereals and lignocellulosic biomass and considering recent implementation plans). In 2030, these sources could potentially yield 2.2 Mton $\mathrm{CO}_{2}$ for electrofuels production (approximately 5.5 times the amount currently available). The largest increase in production capacity is expected with the large-scale implementation of a variety of biomass-gasification-based biofuels, such as synthetic natural gas, DME, or methanol from lignocellulosic biomass. Ethanol produced from lignocellulosic feedstocks could also potentially generate large amounts of highly concentrated biogenic $\mathrm{CO}_{2}$.

\section{Swedish Production Potential for Electrofuels}

Using all the currently recoverable $\mathrm{CO}_{2}$ from the point sources identified in this study to produce electrofuel in the form of methane would yield approximately 224 TWh per year. This corresponds to approximately 2.5 times the current Swedish demand for transportation fuels [approximately 85 TWh per year in 2014 (Swedish Energy Agency, 2015b)]. For electrofuels with lower conversion efficiencies (e.g., methanol and DME), production could instead cover about twice the current demand. Producing 224 TWh per year of electro-methane requires about $448 \mathrm{TWh}$ of electricity (assuming $2 \mathrm{MWh}_{\mathrm{e}} / \mathrm{MWh}_{\text {fuel }}$ ), which corresponds to three times the current Swedish electricity generation [149 TWh (Swedish Energy Agency, 2015a)].

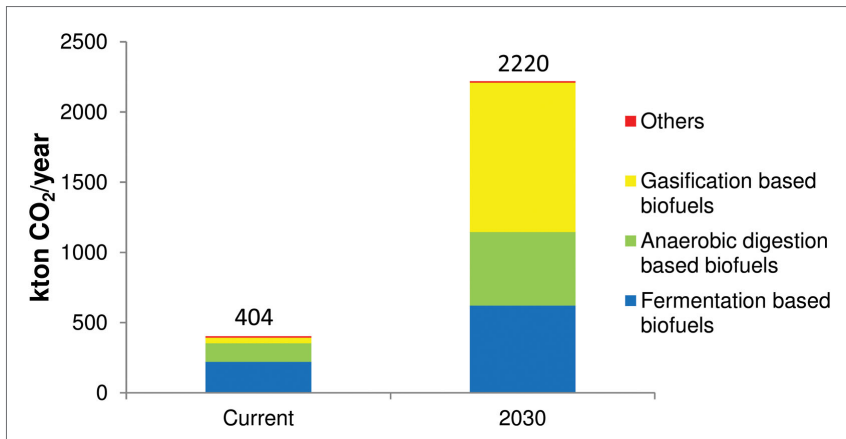

FIGURE 5 | $\mathrm{CO}_{2}$ from high $\mathrm{CO}_{2}$ concentration sources (>90 vol-\%) today and in $\mathbf{2 0 3 0}$

The high-concentration sources, represented mainly by biofuel plants, suffice to provide only about $2 \%$ of the current demand for transportation fuels (corresponding to 1.5-2/year, see Figure 6). Converting the high-concentration emissions to electrofuels would require about 3-4 TWh of electricity (2-3\% of the current national production). In 2030, the potential production of electrofuels in the form of methane, methanol, and DME from high- $\mathrm{CO}_{2}$ sources is $8-11$ TWh (see Figure 6). This corresponds to approximately $9-13 \%$ of the current demand for transportation fuels and would require about 15-21 TWh of electricity (10-14\% of current electricity production).

Table 5 shows the requirements for meeting the current Swedish fuel demand for (non-air) transport with electrofuels in the form of methanol. As seen in Table 5, about half of the recoverable $\mathrm{CO}_{2}$ (23 Mton) would be needed to supply the entire current Swedish road transport demand with electrofuels in the form of methanol (assuming a conversion factor of 0.275 ton $\mathrm{CO}_{2} / \mathrm{MWh}$ methanol). The corresponding amount of $\mathrm{CO}_{2}$ needed to satisfy the entire fuel demand from heavy trucks and all domestic and international shipping currently bunkering in Sweden is estimated to be about 5 and 6 Mton $\mathrm{CO}_{2}$, respectively. This implies that in the case of large-scale introduction of electrofuels for road transport (including heavy trucks), heavy trucks only, or shipping in Sweden, the supply of $\mathrm{CO}_{2}$ is not a limiting factor. 


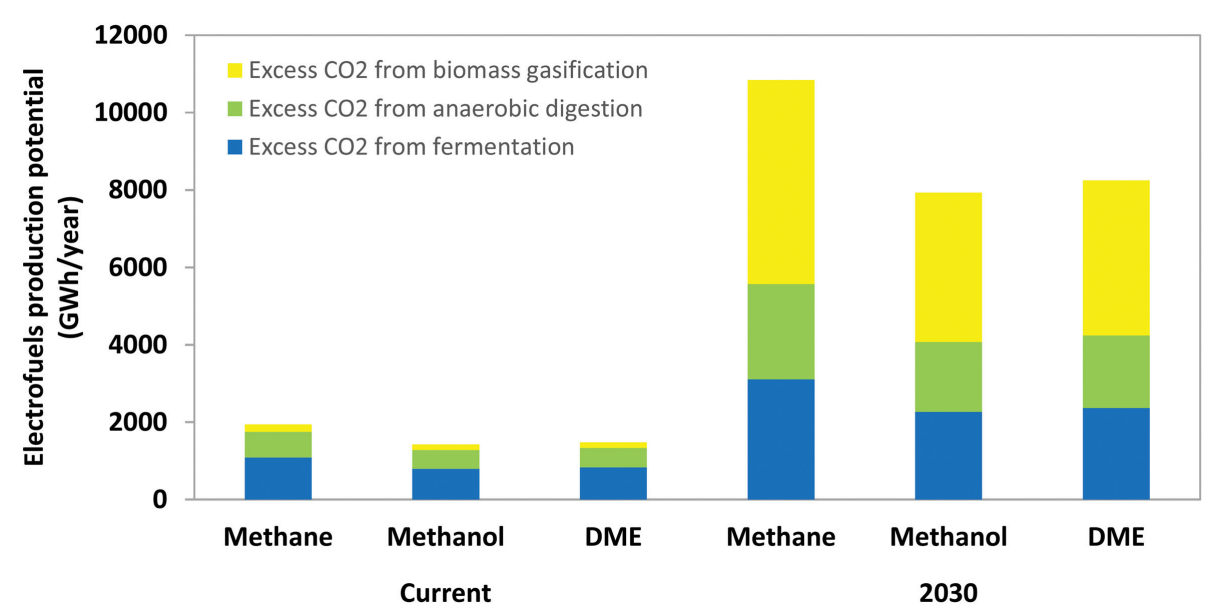

FIGURE 6 | Production potential for electrofuels in the form of methane, methanol and DME from current and future biofuel plants with high $\mathrm{CO}_{2}$ concentrations.

TABLE 5 | Outputs and inputs to electrofuels production if fulfilling the fuel demand with electrofuels in the form of methanol in three different transport modes.

\begin{tabular}{|c|c|c|c|}
\hline & $\begin{array}{c}\text { Road } \\
\text { transport }\end{array}$ & Heavy trucks & Shipping \\
\hline Fuel demand 2014 (TWh) & $\begin{array}{c}85 \text { (Swedish } \\
\text { Energy Agency, } \\
2015 b)\end{array}$ & $\begin{array}{c}18 \text { (Swedish } \\
\text { Government } \\
\text { Official Reports, } \\
\text { 2013) }\end{array}$ & $\begin{array}{c}21 \text { (Swedish } \\
\text { Energy } \\
\text { Agency, } \\
\text { 2015b) }{ }^{b}\end{array}$ \\
\hline Electrofuel replacement (\%) & 100 & 100 & 100 \\
\hline \multicolumn{4}{|l|}{ Electrofuel production } \\
\hline Methanol (TWh) & 85 & 18 & 21 \\
\hline \multicolumn{4}{|l|}{ Electrofuel requirements } \\
\hline Electricity (TWh) & 164 & 35 & 41 \\
\hline Carbon dioxide (Mton) & 23 & 5 & 6 \\
\hline
\end{tabular}

For electricity and $\mathrm{CO}_{2}$ demand per unit of electrofuel see Table 4.

a Expected to increase to approximately 25 TWh by 2050.

${ }^{b}$ Represents the total Swedish use of bunker fuels in 2014 of which $96 \%$ was used for international sea transport.

However, meeting the entire current road transport demand with electrofuels would require about $164 \mathrm{TWh}_{\mathrm{el}}$ of electricity (with methanol at $1.93 \mathrm{MWh}_{\mathrm{el}} / \mathrm{MWh}_{\text {fuel }}$ ). This would more than double the current demand for electricity. To meet the current Swedish fuel demand for passenger cars (at about $41 \mathrm{TWh}$ ) (Swedish Government Official Reports, 2013) with electrofuels in the form of methanol would require approximately 11 ton $\mathrm{CO}_{2}$ and $79 \mathrm{TWh}_{\mathrm{el}}$ of electricity. For comparison, if the entire passenger car fleet were replaced by electric vehicles, the increased demand for electricity would be approximately 10 TWh (based on Swedish Government Official Reports, 2013).

Using electrofuels for the heavy truck sector and for shipping bunker fuel sold in Sweden would require about 35 and $41 \mathrm{TWh}_{\mathrm{el}}$, respectively. For comparison, in 2014, domestic power generation was 150 TWh (SCB, 2016). Further, the goal is to increase domestic generation from renewable sources by about 30 TWh by
2020, compared to 2002 figures and current production of renewable electricity is approximately 85 TWh (SCB, 2016). Large-scale introduction of electrofuels would require a major increase in the supply of electricity from renewable energy sources.

\section{DISCUSSION AND CONCLUSION}

This study shows that Swedish point sources emit approximately 50 million metric tons of $\mathrm{CO}_{2}$ per year, $65 \%$ of which is biogenic in origin. The potentially recoverable emissions amount to 45 Mton. The main point sources are in the pulp and paper industry along with heat and power, while emissions from biofuel production (with relatively high concentrations of recoverable $\mathrm{CO}_{2}$ ) amounted to 0.5 Mton $\mathrm{CO}_{2}$ in 2015 , with an estimated potential for 2.2 Mton $\mathrm{CO}_{2}$ in 2030. Thus, the potential streams of relatively pure $\mathrm{CO}_{2}$ are modest, at least in the near term. Currently, the potential yield from these sources is 1.5-2 TWh of electrofuels per year, corresponding to approximately $2 \%$ of the current Swedish demand for transportation fuels.

However, in Sweden, all types of $\mathrm{CO}_{2}$ emissions, whether fossil or biogenic, and whether low-concentration or high, are of interest in terms of CCU (although carbon capture can be expected to first be applied to systems with higher concentrations of $\mathrm{CO}_{2}$ because capture costs are somewhat lower for these, generally speaking). In the case of electrofuels, as mentioned earlier, it has been indicated that the cost for carbon capture represents a relatively modest share of the total electrofuel-production cost which makes the purity of the $\mathrm{CO}_{2}$ sources less important. However, $\mathrm{CO}_{2}$ from biofuel operations seem like an attractive source since biofuel actors strive to reduce their $\mathrm{CO}_{2}$ emissions due to sustainability requirements. Further, biomass-related $\mathrm{CO}_{2}$ emissions are expected to increase in the future, since the use of biomass for energy is expected to increase while fossil $\mathrm{CO}_{2}$ emissions are expected to decrease.

We conclude that the Swedish supply of $\mathrm{CO}_{2}$ does not have to be a limiting factor for the potential future production of electrofuels for the Swedish transport sector, even if the current 
supply of pure $\mathrm{CO}_{2}$ streams is limited. However, there might be other limiting factors such as the associated electricity demand.

As indicated in the introduction, electrofuels represent a potential long-term energy storage option and could, therefore, be of interest in terms of managing grid-integration of more intermittent renewable energy sources (e.g., wind and solar power). But large-scale introduction of electrofuels in the transport sector would in turn represent a huge new demand for electricity. The direct use of electricity needed to supply the entire current transport demand for passenger cars would increase current electricity demand by $10 \%$, while using electrofuels would require increasing the Swedish electricity generation by about $60 \%$ to meet the same transport demand (Swedish Energy Agency, 2015b). The electrofuels production process and combustion engine are simply that much less efficient than electric motors. Therefore, large-scale introduction of electrofuels might potentially increase the challenge of balancing intermittent renewable generation, rather than help solve it with long-term energy storage, since an increased demand for power would most likely be met with new wind power installations in Sweden. Producing electrofuels only part of the year is one option to limit this problem. However, according to Brynolf et al. (see text footnote 1), the production cost of electrofuels increases drastically per megawatt hours fuel when the capacity factor (i.e., actual production as share of total production capacity) of the wind turbines is decreased. Thus, the benefit of using electrofuels for balancing renewable energy need to be further assessed.

The production cost of different electrofuels is also a limiting factor for the potential future production of electrofuels in Sweden. The literature contains a fairly broad range of estimates, but the most important factors in the production cost of electrofuels are the capital cost of the electrolyzer, the electricity price, the capacity factor of the unit, and the lifetime of the electrolyzer (see text footnote 1).

The majority of the current $\mathrm{CO}_{2}$ sources are located in southern Sweden, which is also the case for the current $\mathrm{CO}_{2}$ sources with relatively pure $\mathrm{CO}_{2}$ emissions. However, from the perspective of the electric-grid, electrofuels production may be more suitable in the northern parts of Sweden where there is generally a surplus of power generation and lower electricity prices. An increasing demand for electricity in southern Sweden might put additional pressure on the transmission capacity from north to south. Future biofuel plants based on forest biomass (as included in the 2030 scenario) are expected to be located mostly in northern Sweden and, therefore, represent an interesting source of $\mathrm{CO}_{2}$ for production of electrofuels.

From a climate perspective, it might be preferable to capture and store $\mathrm{CO}_{2}$ underground, using CCS technology, and not convert $\mathrm{CO}_{2}$ into a fuel that after combustion will be released to the atmosphere again (van der Giesen et al., 2014; Sternberg and Bardow, 2015). If the $\mathrm{CO}_{2}$ has been captured from burning fossil fuels, CCS will avoid increased $\mathrm{CO}_{2}$ concentration, and if the $\mathrm{CO}_{2}$ is captured from burning biomass (or from air), CCS will decrease the atmospheric $\mathrm{CO}_{2}$ concentration, ceteris paribus. Today, however, there are several obstacles that have to be overcome before CCS could be available at a large scale, including public acceptance (Oltra et al., 2010; Dütschke, 2011). CCS is also only applicable for relatively large $\mathrm{CO}_{2}$ sources and storage possibilities depend on geological prerequisites.

The overall impact on $\mathrm{CO}_{2}$ emissions of the production and use of electrofuels mainly depends on the electricity-related $\mathrm{CO}_{2}$ emissions and what the fuels replace (van der Giesen et al., 2014; Sternberg and Bardow, 2015). van der Giesen et al. (2014) conclude that for some production paths, the climate impact is worse than for fossil fuels, and achieving a net climate benefit requires using renewable electricity and renewable $\mathrm{CO}_{2}$ sources. Sternberg and Bardow (2015) evaluate electrofuels relative to the case in which the same amount of $\mathrm{CO}_{2}$ is instead either emitted or stored. They find that electrofuels can at best only make a small contribution to mitigation compared to other available solutions and that using $\mathrm{CO}_{2}$ emissions for electrofuels is worse from a climate perspective compared to storing them. It would be interesting to more thoroughly study the environmental impact of electrofuels compared to other CCU technologies with a lifecycle perspective. For example, the amount of $\mathrm{CO}_{2}$ emissions from electricity production will depend on (i) the time perspective (for example using a marginal or average electricity mix) and (ii) the geographical boundaries of the electricity supply. However, GHG emissions from electricity production are expected to decrease significantly as a consequence of stringent energy and climate policies changing the mix of energy sources.

To summarize, electrofuels are limited by electricity demand rather than the demand for $\mathrm{CO}_{2}$ and, at scale, require a substantial amount of renewable electricity at relatively low cost. The GHG impact of electrofuels compared to other options, in particular CCS, needs to be further assessed.

\section{AUTHOR CONTRIBUTIONS}

$\mathrm{JH}$ is the main author; planned the work and led the writing. $\mathrm{RH}$ was responsible for the mapping and quantification of the major Swedish point sources of $\mathrm{CO}_{2}$ emissions and contributed to further assessments and paper writing. SB, MT, and MG contributed with the electrofuel-production characteristics, participated in the assessment, and contributed to paper writing.

\section{ACKNOWLEDGMENTS}

Financial support from the Swedish Research Council Formas, Nordic Energy Research through the Nordic flagship project Shift (Sustainable Horizons for Transport), the Swedish Energy Agency, and the Swedish Knowledge Centre for Renewable Transportation Fuels (f3) is acknowledged. This publication is partly the result of a project within the Renewable Fuels and Systems Program (Samverkansprogrammet Förnybara drivmedel och system), financed by the Swedish Energy Agency and the Swedish Knowledge Centre for Renewable Transportation Fuels (f3). The f3 Centre contributes, through knowledge based on science, to the development of environmentally, economically, and socially sustainable and renewable transportation fuels, as part of a future sustainable society (see www.f3centre.se). The authors also thank Magnus Fröberg, Scania CV AB, and Paulina Essunger for valuable input. 


\section{FUNDING}

This work has received financial support from (i) the Swedish Research Council Formas via the project titled "Cost-effective choices of marine fuels under stringent carbon dioxide reduction

\section{REFERENCES}

Arvidsson, M., and Lundin, B. (2011). Process Integration Study of a Biorefinery Producing Ethylene from Lignocellulosic Feedstock for a Chemical Cluster. Master thesis, Chalmers University of Technology, Gothenburg, Sweden.

Axelsson, P., Cederlöf, F., and Forslöf, S. (2014). Carbon Dioxide Capture from the Ethanol Industry and Use in Industrial Applications. B.Sc. thesis, Linköping University, Linköping, Sweden.

Benjaminsson, G., Benjaminsson, J., and Rudberg, R. B. (2013). Power to Gas - A Technical Review (El till gas - system, ekonomi och teknik). Malmö, Sweden: Svenskt Gastekniskt Center AB.

Bertuccioli, L., Chan, A., Hart, D., Lehner, F., Madden, B., and Standen, E. (2014). Development of Water Electrolysis in the European Union, Fuel Cells and Hydrogen Joint Undertaking. Lausanne, Switzerland. Available at: http://www. fch.europa.eu/sites/default/files/study\%20electrolyser_0-Logos_0.pdf

Bosoaga, A., Masek, O., and Oakey, J.E. (2009). $\mathrm{CO}_{2}$ capture technologies for cement industry. Energy Procedia 1, 133-140. doi:10.1016/j.egypro.2009.01.020

Chapel, D. G., Mariz, C. L., and Ernest, J. (1999). Recovery of $\mathrm{CO}_{2}$ from Flue Gases: Commercial Trends. Available at: http://citeseerx.ist.psu.edu/viewdoc/ download?doi=10.1.1.204.8298\&rep=rep1\&type $=$ pdf

Chen, G., and Chen, Z. (2010). Carbon emissions and resources use by Chinese economy 2007: a 135-sector inventory and input-output embodiment. Commun. Nonlinear Sci. Numer. Simulat. 15, 3647-3732. doi:10.1016/j.cnsns.2009.12.024

Chen, Q., Lv, M., Tang, Z., Wang, H., Wei, W., and Sun, Y. (2016). Opportunities of integrated systems with $\mathrm{CO}_{2}$ utilization technologies for green fuel \& chemicals production in a carbon-constrained society. J. $\mathrm{CO}_{2}$ Utilization 14, 1-9. doi:10.1016/j.jcou.2016.01.004

Connolly, D., Mathiesen, B. V., and Ridjan, I. (2014). A comparison between renewable transport fuels that can supplement or replace biofuels in a $100 \%$ renewable energy system. Energy 73, 110-125. doi:10.1016/j.energy.2014.05.104

Cuéllar-Franca, R. M., and Azapagic, A. (2015). Carbon capture, storage and utilisation technologies: a critical analysis and comparison of their life cycle environmental impacts. J. $\mathrm{CO}_{2}$ Utilization 9, 82-102. doi:10.1016/j.jcou.2014. 12.001

Dahlgren, S., Liljeblad, A., Cerruto, J., Nohlgren, I., and Starberg, K. (2013). Realiserbar biogaspotential i Sverige år 2030 genom rötning och förgasning. Stockholm, Sweden: WSP.

Damen, K., van Troost, M., Faaij, A., and Turkenburg, W. (2006). A comparison of electricity and hydrogen production systems with $\mathrm{CO}_{2}$ capture and storage. Part A: review and selection of promising conversion and capture technologies. Prog. Energy Combust. Sci. 32, 215-246. doi:10.1016/j.pecs.2005.11.005

Damen, K., van Troost, M., Faaij, A., and Turkenburg, W. (2007). A comparison of electricity and hydrogen production systems with $\mathrm{CO}_{2}$ capture and storage-Part B: chain analysis of promising CCS options. Prog. Energy Combust. Sci. 33, 580-609. doi:10.1016/j.pecs.2007.02.002

de Boer, H. S., Grond, L., Moll, H., and Benders, R. (2014). The application of power-to-gas, pumped hydro storage and compressed air energy storage in an electricity system at different wind power penetration levels. Energy 72 , 360-370. doi:10.1016/j.energy.2014.05.047

Dütschke, E. (2011). What drives local public acceptance - comparing two cases from Germany. Energy Procedia 4, 6234-6240. doi:10.1016/j.egypro.2011. 02.636

European Environment Agency. (2015). European Pollutant Release and Transfer Register. Available at: http://prtr.ec.europa.eu/\#/home

Finkenrath, M. (2011). Cost and Performance of Carbon Dioxide Capture from Power Generation. Paris, France: International Energy Agency (IEA).

Gahleitner, G. (2013). Hydrogen from renewable electricity: an international review of power-to-gas pilot plants for stationary applications. Int. J. Hydrogen Energy 38, 2039-2061. doi:10.1016/j.ijhydene.2012.12.010 targets," (ii) Nordic Energy Research through the Nordic flagship project Shift (Sustainable Horizons for Transport), and (iii) the Swedish Knowledge Centre for Renewable Transportation Fuels and the Swedish Energy Agency via the project titled "The role of electrofuels: a cost-effective solution for future transport?”

Ganesh, I. (2013). Conversion of carbon dioxide into several potential chemical commodities following different pathways-a review. Mater. Sci. Forum 764, 1-82. doi:10.4028/www.scientific.net/MSF.764.1

Goeppert, A., Czaun, M., Surya Prakash, G. K., and Olah, G. A. (2012). Air as the renewable carbon source of the future: an overview of $\mathrm{CO}_{2}$ capture from the atmosphere. Energy Environ. Sci. 5, 7833-7853. doi:10.1039/ C2EE21586A

Government offices of Sweden. (2009). Regeringens Proposition (Government Bill) 2008/2009:163: En sammanhållen Klimat och Energipolitik - Energi respektive Klimat (A Coherent Climate and Energy Policy -Energy and Climate Respectively). Available at: www.regeringen.se/rattsdokument/proposition/2009/03/prop.200809163/ and www.regeringen.se/rattsdokument/proposition/2009/03/ prop.-200809162/

Grahn, M., and Hansson, J. (2015). Prospects for domestic biofuels for transport in Sweden 2030 based on current production and future plans. Wiley Interdiscip. Rev. Energy Environ. 4, 290-306. doi:10.1002/wene.138

Graves, C., Ebbesen, S. D., Mogensen, M., and Lackner, K. S. (2011). Sustainable hydrocarbon fuels by recycling $\mathrm{CO}_{2}$ and $\mathrm{H}_{2} \mathrm{O}$ with renewable or nuclear energy. Renew. Sustain. Energ. Rev. 15, 1-23. doi:10.1016/j.rser.2010.07.014

Grond, L., Schulze, P., and Holstein, S. (2013). Systems Analyses Power to Gas: Deliverable 1: Technology Review. Groningen, the Netherlands: DNV KEMA Energy \& Sustainability.

Hannula, I. (2015). Co-production of synthetic fuels and district heat from biomass residues, carbon dioxide and electricity: performance and cost analysis. Biomass Bioeng. 74, 26-46. doi:10.1016/j.biombioe.2015.01.006

Hannula, I. (2016). Hydrogen enhancement potential of synthetic biofuels manufacture in the European context: a techno-economic assessment. Energy 104, 199-212. doi:10.1016/j.energy.2016.03.119

Hannula, I., and Kurkela, E. (2013). Liquid Transportation Fuels via Large-Scale Fluidised-Bed Gasification of Lignocellulosic Biomass. VTT Technical Research Centre of Finland Report. Available at: http://www.ieatask33.org/download. php?file=files/file/publications/new/Techno-economics.pdf

Hansson, J., and Grahn, M. (2013). Utsikt för förnybara drivmedel i Sverige, IVL report B 2083. Available at: http://spbi.se/wp-content/uploads/2013/03/ IVL_B2083_2013_final.pdf

Heyne, S. (2013). Bio-SNG from Thermal Gasification-Process Synthesis, Integration and Performance. Doctoral thesis, Linköping University, Gothenburg, Sweden.

IEA. (2013). Technology Roadmap - Carbon Capture and Storage. Paris: International Energy Agency.

Johannesson, T. (2016). Implementation of Electrofuel Production at a Biogas Plant - Case Study at Borås. Master thesis, Chalmers University of Technology, Gothenburg, Sweden.

König, D. H., Baucks, N., Dietrich, R. U., and Wörner, A. (2015). Simulation and evaluation of a process concept for the generation of synthetic fuel from $\mathrm{CO}_{2}$ and $\mathrm{H}_{2}$. Energy 91, 833-841. doi:10.1016/j.energy.2015.08.099

Kötter, E., Schneider, L., Sehnke, F., Ohnmeiss, K., and Schröer, R. (2016). The future electric power system: impact of power-to-gas by interacting with other renewable energy components. J. Energy Storage 5, 113-119. doi:10.1016/j. est.2015.11.012

Kuramochi, T., Ramírez, A., Turkenburg, W., and Faaij, A. (2012). Comparative assessment of $\mathrm{CO}_{2}$ capture technologies for carbon-intensive industrial processes. Prog. Energy Combust. Sci. 38, 87-112. doi:10.1016/j.pecs.2011. 05.001

Kuramochi, T., Ramírez, A., Turkenburg, W., and Faaij, A. (2013). Technoeconomic prospects for $\mathrm{CO}_{2}$ capture from distributed energy systems. Renew. Sustain. Energy Rev. 19, 328-347. doi:10.1016/j.rser.2012.10.051

Larsson, M., Grönkvist, S., and Alvfors, P. (2015). Synthetic fuels from electricity for the Swedish transport sector: comparison of well to wheel energy efficiencies and costs. Energy Procedia 75, 1875-1880. doi:10.1016/j.egypro.2015.07.169 
Liu, L. C., Wang, J. N., Wu, G., and Wei, Y. M. (2010). China's regional carbon emissions change over 1997-2007. Int. J. Energy Environ. 1, 161-176.

Mathiesen, B. V., Ridjan, I., Connolly, D., Nielsen, M. P., Vang Hendriksen, P., Bjerg Mogensen, M., et al. (2013). Technology Data for High Temperature Solid Oxide Electrolyser Cells, Alkali and PEM Electrolysers. Aalborg University, Denmark: Department of Development and Planning.

Mignard, D., and Pritchard, C. (2008). On the use of electrolytic hydrogen from variable renewable energies for the enhanced conversion of biomass to fuels. Chem. Eng. Res. Des. 86, 473-487. doi:10.1016/j.cherd.2007.12.008

Mohseni, F. (2012). Power to Gas - Bridging Renewable Electricity to the Transport Sector. Licentitate thesis, KTH Royal Institute of Technology, Stockholm, Sweden.

Naims, H. (2016). Economics of carbon dioxide capture and utilization - a supply and demand perspective. Environ. Sci. Pollut. Res. 23, 22226-22241. doi:10.1007/s11356-016-6810-2

Nikoleris, A., andNilsson,L. (2013). Elektrobränslenen kunskapsöversikt(Electrofuels An Overview). IMES Report Series, Vol. 85. Lund, Sweden: Lund University. Available at: http://portal.research.lu.se/portal/files/3697397/3738230.pdf

Nord Pool. (2016). Historical Market Data. Available at: http://www.nordpoolspot. com/historical-market-data/

Oltra, C., Sala, R., Solà, R., Di Masso, M., and Rowe, G. (2010). Lay perceptions of carbon capture and storage technology. Int. J. Greenhouse Gas Control 4, 698-706. doi:10.1016/j.ijggc.2010.02.001

Pachauri, R. K., Allen, M. R., Barros, V. R., Broome, J., Cramer, W., Christ, R., et al. (2014). Climate Change 2014: Synthesis Report. Contribution of Working Groups I, II and III to the Fifth Assessment Report of the Intergovernmental Panel on Climate Change, eds R. Pachauri, and L. Meyer (Geneva, Switzerland: IPCC), 151.

Perathoner, S., and Centi, G. (2014). $\mathrm{CO}_{2}$ recycling: a key strategy to introduce green energy in the chemical production chain. ChemSusChem 7, 1274-1282. doi: $10.1002 /$ cssc. 201300926

Pettersson, K., and Harvey, S. (2012). Comparison of black liquor gasification with other pulping biorefinery concepts - systems analysis of economic performance and $\mathrm{CO}_{2}$ emissions. Energy 37, 136-153. doi:10.1016/j.energy.2011.10.020

Qadrdan, M., Abeysekera, M., Chaudry, M., Wu, J., and Jenkins, N. (2015). Role of power-to-gas in an integrated gas and electricity system in Great Britain. Int. J. Hydrogen Energy 40, 5763-5775. doi:10.1016/j.ijhydene.2015.03.004

Reiter, G., and Lindorfer, J. (2015). Evaluating $\mathrm{CO}_{2}$ sources for power-to-gas applications - a case study for Austria. J. $\mathrm{CO}_{2}$ Utilization 10, 40-49. doi:10.1016/ j.jcou.2015.03.003

Ridjan, I., Mathiesen, B. V., and Connolly, D. (2014). Synthetic fuel production costs by means of solid oxide electrolysis cells. Energy 76, 104-113. doi:10.1016/ j.energy.2014.04.002

SCB. (2015). Energy Prices and Switching of Suppliers, 3rd Quarter 2015 (Prisutveckling på energi samt leverantörsbyten, tredje kvartalet 2015). Stockholm, Sweden: Statistics Sweden. Available at: www.scb.se/Statistik/EN/ EN0304/2015K03/EN0304_2015K03_SM_EN24SM1504.pdf

SCB. (2016). Tillförsel och användning av el 2001-2015 (GWh) (Production and Use of Electricity 2001-2015). Available at: http://www.scb.se/hittastatistik/statistik-efter-amne/energi/tillforsel-och-anvandning-av-energi/ arlig-energistatistik-el-gas-och-fjarrvarme/tillforsel-och-anvandning-av-el20012015-gwh/

Schiebahn, S., Grube, T., Robinius, M., Tietze, V., Kumar, B., and Stolten, D. (2015). Power to gas: technological overview, systems analysis and economic assessment for a case study in Germany. Int. J. Hydrogen Energy 40, 4285-4294. doi:10.1016/j.ijhydene.2015.01.123

SGC. (2012). Basic Data on Biogas. Report. Malmö, Sweden: Svenskt gastekniskt centrum. Available at: http://www.sgc.se/ckfinder/userfiles/files/ BasicDataonBiogas2012.pdf

Smolinka, T., Günther, M., and Garche, J. (2011). Stand und Entwicklungspotenzial der Wasserelektrolyse zur Herstellung von Wasserstoff aus regenerativen Energien, Kurzfassung des Abschlussberichtes NOW-Studie. Freiburg im Breisgau: Fraunhofer ISE and FCBAT. Available at: http://www.hs-ansbach.de/uploads/ tx_nxlinks/NOW-Studie-Wasserelektrolyse-2011.pdf

ST1. (2016). St1 Built a Waste-Based Etanolix ${ }^{\circledast}$ Ethanol Production Plant in Gothenburg. Available at: http://www.st1.eu/news/st1-built-a-waste-based-etanolixethanol-production-plant-in-gothenburg
Sternberg, A., and Bardow, A. (2015). Power-to-what? - environmental assessment of energy storage systems. Energy Environ. Sci. 8, 389-400. doi:10.1039/ C4EE03051F

Streibel, M., Nakaten, N., Kempka, T., and Kühn, M. (2013). Analysis of an integrated carbon cycle for storage of renewables. Energy Procedia 40, 202-211. doi:10.1016/j.egypro.2013.08.024

Swedish Energy Agency. (2015a). Energy in Sweden 2015. Eskilstuna, Sweden: Swedish Energy Agency. Available at: https://www.energimyndigheten.se/globalassets/statistik/overgripande-rapporter/energy-in-sweden-till-webben.pdf

Swedish Energy Agency. (2015b). Transportsektorns energianvändning 2014 (Energy Use in the Transport Sector 2014). Eskilstuna, Sweden: Swedish Energy Agency.

Swedish Energy Agency and Energigas Sverige. (2015). Produktion och användning av biogas och rötrester år 2014, ES 2015:03. Available at: https://www.energimyndigheten.se/globalassets/nyheter/2015/produktion-och-anvandning-av-biogas-och-rotrester-ar-2014.pdf

Swedish Energy Agency and Energigas Sverige. (2016). Produktion och användning av biogas och rötrester år 2015, ES 2016:04. Available at: https://www.energimyndigheten.se/globalassets/nyheter/2016/es-2016-04-produktion-och-anvandning-av-biogas-och-rotrester-ar-2015.pdf

Swedish Energy Markets Inspectorate. (2014). Sverige är indelat i fyra elområden. Fact Sheet. Available at: http://ei.se/Documents/Publikationer/fakta_och_ informationsmaterial/Elomraden.pdf

Swedish Government Official Reports. (2013). Fossilfrihet på väg (On Its Way to Fossil Fuel Independence). SOU 2013:84. Available at: http://www.regeringen.se/ rattsdokument/statens-offentliga-utredningar/2013/12/sou-201384/

Swedish Government Official Reports. (2016). En klimat - och luftvårdsstrategi för Sverige - Del 1 (A Climate and Air Pollution Treatment Strategy for Sweden Part 1). Delbetänkande av Miljömålsberedningen, Swedish Government Official Reports SOU 2016:47. Available at: http://www.regeringen.se/rattsdokument/ statens-offentligautredningar/2016/06/en-klimat-och-luftvardsstrategifor-sverige/

Taljegård, M., Brynolf, S., Hansson, J., Hackl, R., Grahn, M., and Andersson, K. (2015). "Electrofuels - a possibility for shipping in a low carbon future?" in Proceedings of International Conference on Shipping in Changing Climates. Glasgow, 405-418.

Tremel, A., Wasserscheid, P., Baldauf, M., and Hammer, T. (2015). Technoeconomic analysis for the synthesis of liquid and gaseous fuels based on hydrogen production via electrolysis. Int. J. Hydrogen Energy 40, 11457-11464. doi:10.1016/j.ijhydene.2015.01.097

Trost, T., Jentsch, M., and Sterner, M. (2012). Erneuerbares Methan: Analyse der $\mathrm{CO}_{2}$-Potenziale für Power-to-Gas Anlagen in Deutschland. Zeitschrift für Energiewirtschaft 36, 173-190. doi:10.1007/s12398-012-0080-6

van der Giesen, C., Kleijn, R., and Kramer, G. J. (2014). Energy and climate impacts of producing synthetic hydrocarbon fuels from $\mathrm{CO}_{2}$. Environ. Sci. Technol. 48, 7111-7121. doi:10.1021/es500191g

Vandewalle, J., Bruninx, K., and D'haeseleer, W. (2014). The Interaction of a High Renewable Energy/Low Carbon Power System with the Gas System through Power to Gas. Rome, 28-31.

Varone, A., and Ferrari, M. (2015). Power to liquid and power to gas: an option for the German Energiewende. Renew. Sustain. Energ. Rev. 45, 207-218. doi:10.1016/j.rser.2015.01.049

Wismans, J., Grahn, M., and Denbratt, I. (2016). Low-Carbon Transport: Health and Climate Benefits. Background Report to Intergovernmental Ninth Regional Environmentally Sustainable Transport (EST) Forum in Asia. Gothenburg: Chalmers University of Technology.

Xu, Y., Isom, L., and Hanna, M. A. (2010). Adding value to carbon dioxide from ethanol fermentations. Bioresour. Technol. 101, 3311-3319. doi:10.1016/ j.biortech.2010.01.006

Zakeri, B., and Syri, S. (2015). Electrical energy storage systems: a comparative life cycle cost analysis. Renew. Sustain. Energ. Rev. 42, 569-596. doi:10.1016/ j.rser.2014.10.011

Zhang, B., and Chen, G. (2014). China's $\mathrm{CH}_{4}$ and $\mathrm{CO}_{2}$ emissions: bottom-up estimation and comparative analysis. Ecol. Indicators 47, 112-122. doi:10.1016/ j.ecolind.2014.01.022

Zhang, X., Chan, S. H., Ho, H. K., Tan, S. C., Li, M., Li, G., et al. (2015). Towards a smart energy network: the roles of fuel/electrolysis cells and 
technological perspectives. Int. J. Hydrogen Energy 40, 6866-6919. doi:10.1016/ j.ijhydene.2015.03.133

Conflict of Interest Statement: The authors declare that the research was conducted in the absence of any commercial or financial relationships that could be construed as a potential conflict of interest.
Copyright ( 2017 Hansson, Hackl, Taljegard, Brynolf and Grahn. This is an openaccess article distributed under the terms of the Creative Commons Attribution License (CC BY). The use, distribution or reproduction in other forums is permitted, provided the original author(s) or licensor are credited and that the original publication in this journal is cited, in accordance with accepted academic practice. No use, distribution or reproduction is permitted which does not comply with these terms. 